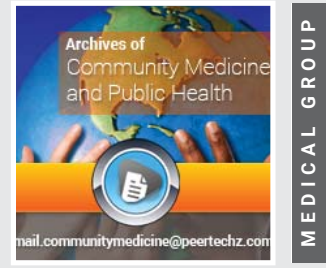

\section{Mental health during the COVID-19 epidemic: The role of social media}

\author{
Iraj Salehi ${ }^{1}$, Sajjad Solymani ${ }^{2}$ and Elahe Ezati ${ }^{3 *}$ \\ 1Professor of Physiology, Department of Anesthesiology, School of Allied Medical Sciences, Chronic \\ Diseases (Homecare) Research Center, Hamadan University of Medical Sciences, Hamadan, Iran \\ ${ }^{2}$ Ph.D, Clinical Psychology, Asadabad School of Medical Sciences, Asadabad, Iran \\ ${ }^{3}$ Ph.D, Health Education \& Promotion, Assistant Professor, Asadabad School of Medical Sciences, \\ Asadabad, Iran
}

Received: 30 December, 2021

Accepted: 11 January, 2022

Published: 12 January, 2022

*Corresponding author: Elahe Ezati, Ph.D, Health Education \& Promotion, Assistant Professor, Asadabad School of Medical Sciences, Asadabad, Iran, Email: elahe.ezati@gmail.com

Copyright License: (c) 2022 Salehi l, et al. This is an open-access article distributed under the terms of the Creative Commons Attribution License, which permits unrestricted use, distribution, and reproduction in any medium, provided the original author and source are credited.

https://www.peertechzpublications.com

\section{Check for updates}

Currently, the COVID-19 pandemic is one of the major health issues in the world [1,2]. In December 2019, a population of patients with pneumonia of unknown etiology was found in Wuhan, China. Many of the first patients were associated with a local seafood shop and live wild animals [1]. Therefore, it was initially thought that the disease was transmitted from animal to human. But after closing the said shop, the number of infected cases increased and it seemed that the second method of transmission of this disease was human-to-human [3].

These conditions made the transmission more contagious and made it harder to control the virus. The growing prevalence of COVID-19 in the world has become an important health warning and on the other hand, exposure to COVID-19 can include experiences such as coronavirus infection, hospitalization due to coronavirus or the death of a loved one, and because it causes psychological damage and can last for a long time it ultimately leads to reduced quality of life and functional impairments in the social, occupational, and physical domains [4].

During the COVID-19 pandemic, a report published by the Centers for Disease Control and Prevention (CDC)Trusted Source found that of the adults surveyed in the United States: $31 \%$ reported symptoms of anxiety or depression. $13 \%$ reported having started or increased substance use. $26 \%$ reported experiencing stress-related symptoms and $11 \%$ reported having suicidal thoughts [5].

Compared with traditional media, social media has played a multitude of positive roles in information exchange during the COVID-19 crisis, including disseminating health-related recommendations, enabling connectivity and psychological first aid, showing public attitudes, experiences, and perception of the disease as well as sentiment to the government. On the other hand, social media has also fueled the rapid spread of misinformation and rumors, which can create a sense of panic and confusion among the public [6].

Due to social media, people are more engaged and connected, which increases information sharing while at the same time allowing sensationalism and misinformation to spread regarding COVID-19 because shocking or emotionally charged content gets people's attention. Consequently, experts say.

Social media makes people more anxious about what is to come [5].

Also, Preliminary research on COVID-19 has shown that among adults in China, hearing negative news about COVID-19 on social media can lead to negative emotions, anxiety, and depression [2].

This information can be distressing and potentially affect people's mental health, as a result, people are more exposed to COVID-19 [7-9].

Social media platforms have contributed to the spread of false news and conspiracy theories during the new coronavirus pandemic. When analyzing the potential risks of misinformation, panic, depression, fear, fatigue, and the risk of infection influence psychological distress and emotional overload. In the COVID-19 pandemic, the disposition to spread incorrect information or rumors is directly related to the development of anxiety in populations of different ages [10]. 
The mental health status of the public following the Prevalence of COVID-19 is a major issue of concern. Excessive social media exposure to this public health crisis might lead to heightened acute stress and long-term psychological distress [11].

\section{References}

1. Hasell J, Mathieu E, Beltekian D, Macdonald B, Giattino C, et al. (2020) A cross-country database of COVID-19 testing. Sci Data 7: 1-7. Link: https://bit.ly/3zWQJzl

2. Bulut C, Kato Y (2020) Epidemiology of COVID-19. Turkish J Med Sci 50: 563570. Link: https://bit.ly/3tiveHX

3. Lipsitch M, Swerdlow DL, Finelli L (2020) Defining the Epidemiology of COVID-19 - Studies Needed. N Engl J Med 382: 1194-1196. Link: https://bit.ly/3fc8dhL

4. Wangping J, Ke H, Yang S, Wenzhe C, Shengshu W, et al. (2020) Extended SIR prediction of the epidemics trend of COVID-19 in Italy and compared with Hunan, China. Front Med 7: 169. Link: https://bit.ly/3tkb4NH

5. The current state of mental health. Link: https://bit.ly/34KkIED
6. Muhammad N (2021) Do social media platforms develop consumer panic buying during the fear of COVID-19 pandemic. Journal of Retailing and Consumer Services 58: 102226. Link: https://bit.ly/3qhl88e

7. Choi S, Ki M (2020) Estimating the reproductive number and the outbreak size of COVID-19 in Korea. Epidemiol Health 42: e2020011. Link: https://bit.ly/3nkYUk2

8. Rocha YM, de Moura GA, Desidério GA, de Oliveira CH, Lourenço FD, et al. (2021) The impact of fake news on social media and its influence on health during the COVID-19 pandemic: A systematic review. Z Gesundh Wiss 1-10. Link: https://bit.ly/3HWaZUv

9. Chen B, Bryer T (2012) Investigating instructional strategies for using social media in formal and informal learning. Int Rev Res Open Distributed Learning 13: 87-104. Link: https://bit.ly/3zMuA6Q

10. Czerkawski B (2016) Blending formal and informal learning networks for online learning. Int Rev Res Open Distributed Learning 17. Link: https://bit.ly/3nkGTIH

11. Holman EA, Garfin DR, Lubens P, Silver RC (2019) Media exposure to collective trauma, mental health, and functioning: Does it matter what you see? Clin Psychol Sci 8: 111-124. Link: https://bit.ly/3zR0xuF
Discover a bigger Impact and Visibility of your article publication with Peertechz Publications

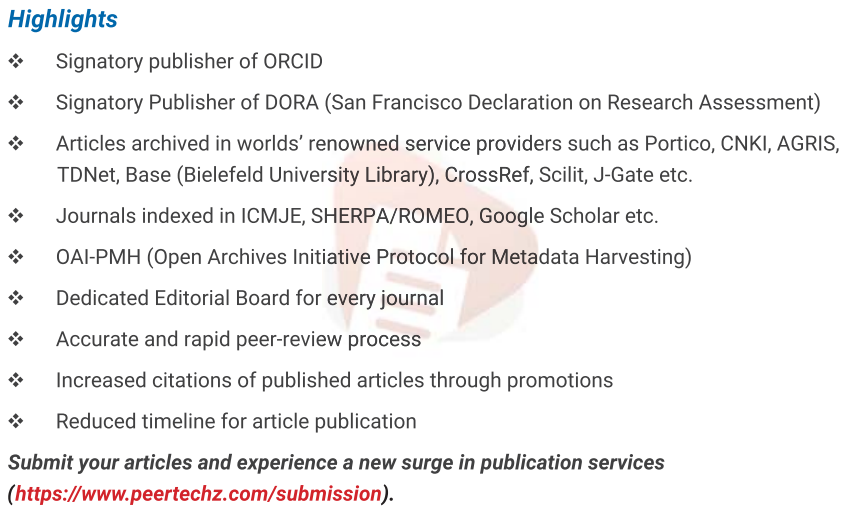

